\title{
DENTISTRY
}

Avetikov D.S., Bashtan V.P., Stavitskiy S.A., Lokes K.P., Aipert V.V.

\section{THE INCIDENCE OF ORAL MALIGNANCIES IN POL- TAVA REGION IN 2011-2015}

\author{
Poltava Ukrainian Medical and Stomatological Academy \\ Poltava, Ukraine
}

\begin{abstract}
Poltava region is represented in the work. There is a high prevalence of neglected tumors $(45,3 \%)$ of this location together with significant amount of treatment refusal and $31.8 \% 1$-year mortality after diagnosis were established. 794 cases of oral cavity malignant neoplasms in Poltava region were registered during 20122016 yy. with $26.95 \%$ from urban and $73.04 \%$ from rural areas. There are $174(22.16 \%)$ cases in females and 618 (77.84 \%) cases in males were observed (male to female ratio is 3,5 ). Total 1 -year mortality is 306 cases.
\end{abstract}

The first place in cancer structure is placed by cancer of lips - 355 people, the second one - cancer of the oral floor (147 cases). Other forms and unspecified parts of tongue - 96 cases, tongue - 75, palate - 67 and malignant neoplasm of gums - 54 cases.

KeyWords: morbidity, oncology, oral cavity, precancerous condition, malignant neoplasms.

\section{INTRODUCTION}

The article deals with the assessment of the incidence of oral malignancies in Poltava region for 4 years, from 2011 to 2015. There is a high incidence of neglected tumors of the named localization (it's about $31.8 \%$ ). Numerous refusals of treatment due to different circumstances were observed.

Malignant tumors are a major biomedical, social and economic problem not only in Ukraine but also in the world. The incidence and cancer mortality are steadily growing, increasing the risk due to the unstable economic situation in the country, unfavorable ecological situation and a significant aging of the population [1, 2].

The problem of cancer, especially malignant tumors is one of the most pressing in modern medicine. According to WHO, each year approximately 4.3 million people die from cancer in the world. Cancer is among the three leading causes of death in all the age groups over 50 years, both in the developed countries and in the developing ones [3, 4].

\section{Corresponding Author:}

Aipert Viktoriya - MD, PhD, Assistant of Professor, Department of surgical stomatology and maxillofacial surgery with plastic and reconstructive surgery of head and neck, Ukraine, Email: viktoriya_ishchenko@ukr.net
Malignant tumors of the head and neck (excluding skin, eyes and brain) constitute about $5 \%$ of cancers in other locations. Cancer of the oral cavity and oropharynx ranks second among head and neck malignancies after cancer of the larynx, and their ratio is $2-10 \%$ of all human cancers.

However, this number of patients is considered significant because the disease results in an extremely severe dysfunction of breathing, swallowing, speech and appearance. The severity is primarily determined by the advanced and often incurable forms of disease, while advanced forms of cancer in other locations lead to death from certain metastases $[5,6,7]$.

Combating malignant tumors is a major public health problem in Ukraine. The urgency of this issue is determined by the constantly growing incidence of malignant tumors in population, early diagnosis difficulties, high cost and difficulty of treatment, high disability and mortality rates.

Each year about 200,000 new cases of malignant tumors are registered in Ukraine.

Oncologic and epidemiologic situation in Ukraine and in some of the regions basing on long-term monitoring data is characterized by a continuous growth of cancer-related 
morbidity. Thus, in 1980 the number of newly registered patients was 238.3 per 100,000 population and in 1996 this value reached 309.4, while in 2010 the incidence of malignant neoplasms in Ukraine amounted to 341.2 per 100,000 population. Each year cancer affects more than 160,000 people. This means that every day in Ukraine 442 new patients develop cancer or 18 cases per every hour. These figures indicate the intensity and magnitude of the problem. Each third or fourth man and every fifth or sixth woman has a risk of getting cancer within the lifespan [8].

\section{PURPOSES, SUBJECTS and METHODS:}

\subsection{Purpose}

The aim of the article was to compare the incidence of oral malignancies in Poltava region in 2011-2015, identifying social-organizational problems of diagnosis and possible ways to improve them.

\subsection{Subjects \& Methods}

The study involved the assessment of incidence of oral malignancies in Poltava region for the last 4 years (2011-2015) with the following locations: jaw, palate, tongue and other locations, such as lips and oral floor.

\section{Conflict of interests}

There is no conflict of interests.

\section{RESULTS AND DISCUSSION}

All cancer patients were divided into groups according to their age by the WHO classification (WHO classification, 1963): Group 1 - patients under 45 years; Group 2 - 45-59 years; Group 3 - 60-74 years; Group 4 - 75-89 years; Group 5 - over 90 years.

Jaw cancer. The total number of cases from 2010 to 2014 was 54 people (representing $6.8 \%$ of the total number of patients). The distribution by sex was as follows: 13 women and 41 men. The study showed that 26 people were diagnosed at stage III of the disease and 12 people at stage IV; 18 patients were registered in cities and 36 patients in villages; annual mortality rate was 39 people.

Neoplasms of the palate. The study involved the assessment of 67 cases for the period of 4 years, $8.438 \%$ of all the patients with cancer of the mouth, including 11 women and 56 men. Annual mortality was 38 deaths. In 24 patients cancer was diagnosed at the III stage and in 8 cases at stage IV. Of them 24 men lived in the city and 43 people lived in the village.

Tongue cancer. The total number of 75 patients $(9.445 \%)$ attended Poltava Regional Oncology Center from 2010 to 2014. Only 14 of them received comprehensive treatment. Thus, 28 people received chemotherapy, 40 people underwent radiotherapy, 11 patients refused from any treatment for unknown reasons and 10 patients underwent surgical treatment. Furthermore, 43 people died within one year, 34 cases were diagnosed at stage III, and 13 at stage IV.

Lip cancer. The total number of patients with lip cancer for the entire period under investigation was 355 (44.72\%); 256 men, 99 women; 274 patients lived in villages. Diagnosis was made at stage III in 81 patients, at stage IV in 41 patients; annual mortality rate was 64 cases.

Malignant tumors of the oral floor. The total number of people with this type of cancer from 2010 to 2014 was 147 cases (18.513\%). Of them 94 were from villages, 53 people lived in cities. There were 141 men, 6 women; 93 patients were diagnosed at stage III, 21 patients at stage IV. Annual mortality rate was 69 cases.

\section{CONCLUSIONS}

The total number of patients with oral malignancies in Poltava region from 2010 to 2014 was 794 . The quantity of urban residents was 214 (26.95\%), rural residents - 580 (73.04\%) patients (exceeding the number of city residents by 2.71 -fold). All the patients were divided according to gender: 174 (22.16\%) women, 618 (77.84\%) men, which by 3.55-fold exceeds the number of women; annual mortality rate reached 306 cases. According to age the patients were divided as follows: Group 1 (45 years) - 8 people, Group 2 (45-59 years) - 160 cases, the highest number of cases was recorded in Group 3 (60-74 years) - 350 people, Group 4 (75-89 years) - 215 people, Group 5 (> 90 years) - 25 regis- 
4. Kaluzhna L.D., Bilokliscka G.F. (2007) Chvorobi shkiri oblichcha, slizovoi obolonki porozhnini rota ta chervonoi obliamivki gub [The diseases of face skin, oral mucosa and red border of lips]. Text-book. Kiev. Gramota. 207 p.

5. Adams, C. L., Chen, Y. T., Smith, S. J. (2013) Mechanisms of epithelial cell-cell adhesion and cell compaction revealed by high-resolution tracking of $\mathrm{E}$ cadherin-green fluorescent protein. J Cell Biol. 142, 110519.

6 Grigorchuk Yu.F., Ruzin G.P. (1998) Osnovnie principi diagnostiki i lecheniya predrakovih zabolevaniy chelyustno-litcevoj oblasti [General principle of diagnostic and treatment of precancer diseases of maxilla-facial area]. Charkov, $16 \mathrm{p}$.

7 Danilevskiy $\quad$ N.F. (2001) Zabolevaniya slizistoj obolochki polosti rta [Diseases of oral mucosa]. Moscow, Stomatology. $217 \mathrm{p}$.

8. Avetikov D.S., Lokes K.P., Stavytskyi S.O., Danylchenko S.I., Tkachenko I.M. (2014) Oncologic Alarm in Dental Practice. American Journal of Scientific and Educational Research. 1(4), 547-552.

Received: 20-Jan. - 2017

Accepted: 20-Mar. - 2017
Maxillofacial area can be easily examined both by a doctor and by the patient. However, cancer symptoms are sometimes so mild that the transition of chronic inflammatory or destructive process into malignant growth often goes unnoticed either by a specialist or the patient.

\section{REFERENCES}

1. Colosanto, S., Rossi, L. (2011) Clinical considerations and statistical analysis on 100 patients with oral lichen planus. Minerva stomatol., 49(9), 393-398.

2. Conacci-Sorrell, M., Zhurinsky, J., Ben-Ze'ev, A. (2014) The cadherin-catenin adhesion system in signaling and cancer. J Clin Invest. 109, 987-91.

3. Crissman, J.D., Gluckman, J., Whiteley, J., Quenelle, D. (2010) Squamous-cell carcinoma of the floor of the mouth. Head Neck. 3, 2-7. 